2010 VOLUME 13 No 3 


\section{FUZZY LAW AND THE BOUNDARIES OF SECULARISM}

\section{W Menski ${ }^{* *}$}

\section{Part I}

First, let me thank Prof Marie-Claire Foblets, Dr Prakash Shah and the whole team organising RELIGARE for inviting me to speak tonight at one of the top three law schools of the country. Well done, Queen Mary! It is also a special delight to thank you, Prof Roger Cotterrell, for being our chair tonight and to express my gratitude for your generous introduction.

I may be a pluralist, but am not a fan of fuzziness, so I relish the chance to help RELIGARE's search for more certainty and respect regarding the manner in which we deal with the legal challenges of a multicultural Europe. After the successful kickoff meeting in Leuven and Brussels on 4 to 5 February 2010, this second project seminar is making significant progress in defining the work programmes, and we are even beginning to look at first results.

Early developments confirm that the RELIGARE project is not without its own ideological difficulties. The exit of a major country team indicates that Europe-wide there is still only fuzzy agreement on the project's underlying concepts. We thought that Tariq Modood in his public lecture in Leuven had consolidated the agenda, ${ }^{1}$ highlighting that law and religion are necessarily linked and that states not only cannot avoid considering religion, but have an interest in doing so in an increasingly multicultural environment. Europe cannot just disregard religion in all its various manifestations in the twenty-first century. Political secularism of necessity links law and religion through ties of policy and practice. While radical secularism, the absolute, total separation of law and religion is manifestly unreal, as the French

\footnotetext{
** Werner Menski. Professor of South Asian Laws, School of Law, SOAS, University of London and Member of the Advisory Board of RELIGARE (wm4@soas.ac.uk).

1 Modood T 2010 "Moderate secularism, religion as identity and respect for religion" (Keynote presentation at the RELIGARE kick-off meeting 4 February 2010 Leuven). See also Modood T Multiculturalism. A Civic Idea (Polity Cambridge 2007).
} 
should have learnt by now, moderate secularism with genuine efforts at relative separation is maybe the way forward. But how does one go about this? Moderate secularism, as I shall demonstrate, is not just another fuzzy concept; it is superfuzzy. Another problem appears to be that whilst lawyers claim to love certainty, they have a tendency to sit in judgment over matters and even pre-judge things they know little about, including legal pluralism. Unsurprisingly, that can lead to much irritation.

This lecture builds on earlier foundations but attempts to propel us collectively into a brighter sky over Europe. I want to fly a kite, but more about that later. Forget that ash clouds, the effects of terrorism and intolerance of various kinds pose major threats to our well-being today. Since law, culture and religion as co-existing and competing entities have to be combined everywhere into new forms of "living law", that old and still very useful concept, ${ }^{2}$ there is constant need for compromise, and questions on the boundaries of secularism arise everywhere. The case collections that RELIGARE promises to provide will document the compromises that have already been attempted, or may have failed, and this material will offer important indications for future directions.

The fuzzy title chosen for this talk is designed to reflect that the underlying plurality of post-migration Europe, referred to as "super-diversity" for Britain, ${ }^{3}$ forces us to reconsider whether our existing categories and legal frameworks are useful, or whether we need new terms, concepts and methods to handle the growing diversities around us today. We need to think in more depth about the risks of combining law with religion and culture at the beginning of the twenty-first century, despite predictions of the death of God and the disappearance of religion as a legal entity. None of that happened, as far as we know. ${ }^{4}$ If radical anti-religious secularism is not a feasible option, and erecting walls of separation around "law" and "religion"

2 See Ehrlich E Grundlegung der Soziologie des Rechts (Duncker \& Humblot München 1913); Ehrlich E Fundamental Principles of the Sociology of Law (Harvard University Press Cambridge 1936).

3 Vertovec S "Super-diversity and its implications" 2007 Ethnic and Racial Studies 30(6) 10241054.

4 Prof Roger Cotterrell, in his introduction, confirmed the widespread surprise amongst scholars about the re-emergence of religion in legal discourses. See also his foreword in Shah P (ed) Legal Pluralism in Conflict: Coping with Cultural Diversity in Law (Glasshouse Press London 2005) ix-xi, with further references. 
is not possible because everything is interlinked and fuzzy, these negotiable boundaries will simply be crossed in many ways, no matter how many obstacles and barbed wire regulatory systems of various kinds we may seek to invent. Welcome to borderland studies, a truly exciting interdisciplinary field of pluralist exploration.

The resulting fuzziness gives rise to complex litigation, much academic debate, and even wars. My basic message is a rather positive one, though. Growing awareness that we cannot avoid the challenges of plurality and pluralism (and it does not seem to matter whether we use either term) implies that we are already doing well in opening our eyes to the challenges before us. Lawyers are presently revising their judgments about plurality and have begun to notice a growing gap between legal theory and legal practice in a variety of fields related to "globalisation". ${ }^{5}$ RELIGARE is a flagship project in this respect that may prove to be a life-saving exercise.

I first discuss the reasons that law, religion and secularism are all fuzzy and constantly challenge us to navigate porous boundaries. The internal plurality of every major concept dealt with here is now presentable as a refined pluralism model built on the notion of "pop": simply "plurality of pluralities". ${ }^{6}$ Instead of presenting an irritating cacophony of voices, I shall attempt to deliver a kind of "pop concert" with some harmonious sounds. The orchestra of pluralism will be heard more clearly as I speak. I also have a rather hopeful sub-title for this lecture, but shall hold back on that for the moment.

\section{Part II}

So, where does one begin in this fuzzy talk? The title asserts that law itself is fuzzy, by which I indicate firmly that legal pluralism is a fact, whether we like it or not. So here is a picture of the plurality of laws from my "blue bible", ${ }^{7}$ and I beg indulgence of those who have seen this before. The trouble is, even though this image has been in

5 See the perceptive review of two new European volumes of essays on globalisation and multicentricity by Richards S 2010 Cambridge Law Journal 69(2) 417-420, which clearly identifies "a conceptual mismatch between legal theory and legal practice" (420).

6 This pluralism concept has been developed very recently. For details see Menski W "Sanskrit law: Excavating Vedic legal pluralism" 2010 SOAS School of Law Research Paper 05 http://bit.ly/hnwqev [date of use 29 Nov 2010].

7 Menski W Comparative Law in a Global Context: The Legal Systems of Asia and Africa $2^{\text {nd }}$ ed (Cambridge University Press Cambridge 2006) 612. 
the public domain since 2006, many people, including myself, have not bothered to study this carefully enough and remain unclear particularly regarding the practical implications of the messages from this visual representation.

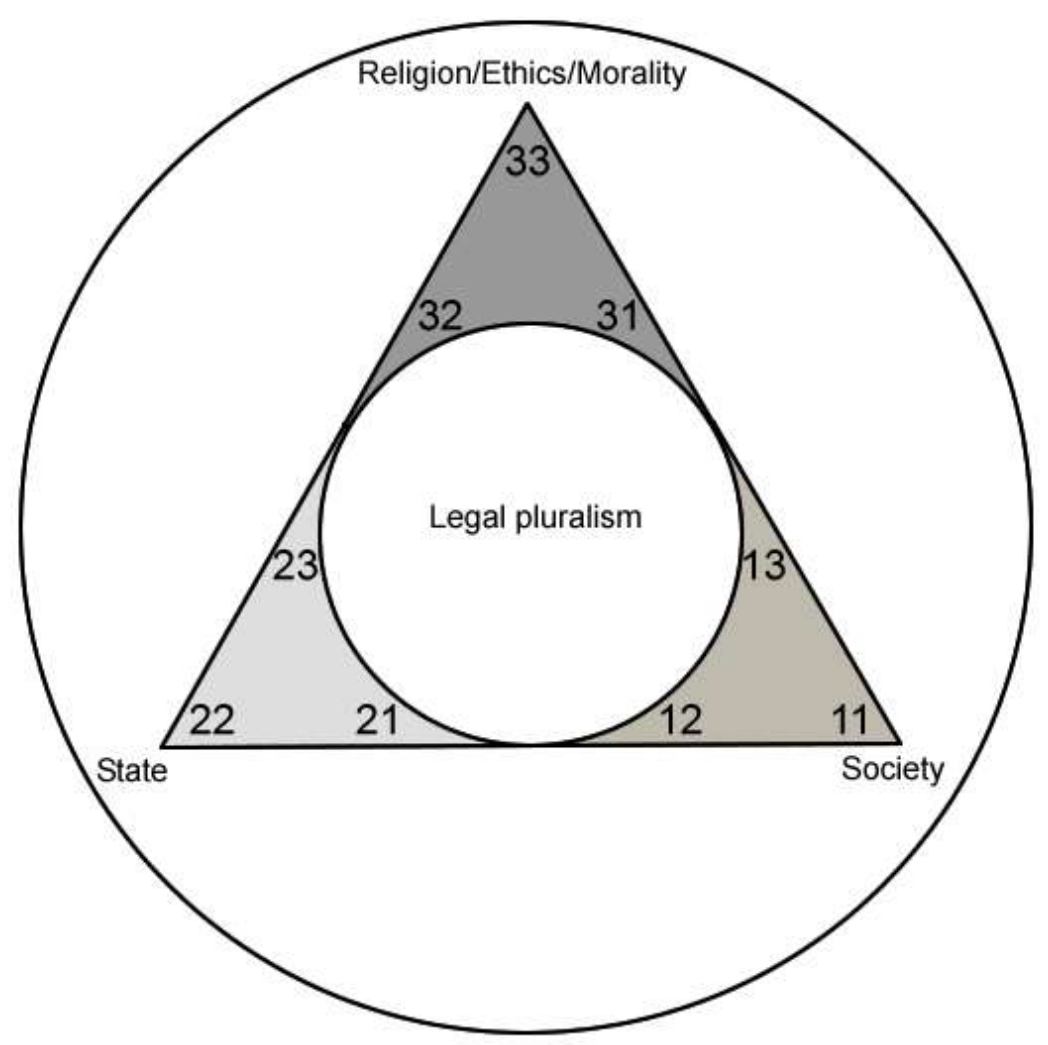

This model builds on earlier legal pluralism studies. Merry's important work was certainly not the first. ${ }^{8}$ The phenomenon itself is apparently ancient: I published recently a study on legal pluralism in Vedic India. ${ }^{9}$ John Griffiths asserted famously in 1986 that legal centralism is a myth and legal pluralism is a fact. ${ }^{10}$ Prof Chiba from Japan repeatedly highlighted the interconnected nature of law, ${ }^{11}$ and many others followed. But repeating the mantras of pluralism should not mean that we can sit back now and think we have found nirvana. The challenges have only just begun.

8 Merry SE "Legal pluralism" 1988 Law and Society Review 22(5) 869-896.

9 See $n 7$ above.

10 Griffiths J "What is legal pluralism?" 1986 Journal of Legal Pluralism and Unofficial Law 24 1-56.

11 Chiba M (ed) Asian Indigenous Law in Interaction with Received Law (KPI London 1986); Chiba M Legal Pluralism: Towards a General Theory through Japanese Legal Culture (Tokai University Press Tokyo 1989); Chiba M Legal Cultures in Human Society: A Collection of Articles and Essays (Shinzansha International Tokyo 2002). 
Good legal theory needs to prove its worth in reality. So what are the practical implications of pluralist models? How fuzzy can all of this become before it sinks into a nihilist free-for-all, as we are constantly told? There appears to be growing consensus now that legal theorising in pluralism studies has reached a state not of perfection, but rather of saturation. The urgent need now is to consider practical methods of handling the fuzziness of law, to understand better why and how choices are made from the register of what I term "pop" elements, and then to define acceptable boundaries. The risk is, however, that such applied research will result in a huge collection of descriptive fuzzy sets of conflict scenarios that leave us even more confused. So we need to continue to think theory and practice at the same time.

Some of course would still like to doubt that legal pluralism is a fact. At an earlier conference, Prof Matthias Rohe, a leading member of RELIGARE, argued against the notion of legal pluralism, saying that German law could do without the fuzziness of pluralist analysis. The German Constitution is an excellent example of positive law because, having learnt from history, it assiduously takes account of various values and ethics and also accounts for local people's social norms through the strong federal system. While that is all correct, this chain of arguments simply confirms positivist myopia. If one looks at the world through the perspective of the state, corner 2 in the above diagram, as lawyers are systematically trained to do, everything else a bit farther away, though still fuzzily connected, can just be kept hidden from view so that there appears to be no fuzziness. That doctrinally focused positivist lawyers should not really look at the world from any other angles remains of course the mantra of mainstream legal education. ${ }^{12}$

Too bad, I say, for this positivist colonising of the interlinked reality of law belittles the presence of the other types of law that positivist theorising actually needs to succeed in constructing good law, as Prof Rohe's argument itself admits. Prof Hart also

12 Prof Rohe happily joined RELIGARE as a key member. Some of his German colleagues apparently perceive him as an apostate of pure positivism, not helped by the fact that he publishes excellent books on Islamic law. See Rohe M Der Islam - Alltagskonflikte und Lösungen: Rechtliche Perspektiven (Herder Freiburg 2001); Rohe M Muslim Minorities and the Law in Europe: Chances and Challenges (Global Media Publications New Delhi 2007); Rohe M Das islamische Recht: Geschichte und Gegenwart (CH Beck Verlag München 2009). 
sensed that earlier, but finally could not acknowledge those linkages because of his positivist mental chains and a good dose of European hubris. ${ }^{13}$ Today we recognise increasingly that even a good state law is not actually just state law when we gaze at the full, fuzzy wider picture. Moreover, as Roger Ballard reiterated earlier today, also in the Eurozone, many people will take other perspectives than state law and will start their choice-making as thinking individuals, not as robot citizens. ${ }^{14}$ Individuals as well as social and religious groups may simply seek to avoid contact with the official law altogether because the state is not always a friend; no state law can totally control that reluctance to engage. Do we then just say that these other perspectives create or constitute a lawless zone, a term we love to use for tribal areas in Afghanistan or other parts of the global South? Or are we still claiming that non-state law is not really law? There is some intellectual turbulence here, especially in the positivistic Eurozone, causing major irritations.

You will notice this repeated flagging up of the Euro-element. This is firstly because RELIGARE focuses on Europe. Secondly, I emphasise the dangers of Eurocentric hubris, exemplified by Prof Hart, who for many anglophile lawyers all over the world remains the god of positivism. Thirdly, I highlight the culture-specific nature of European laws with the strong influence of the Enlightenment and accompanying control mechanisms devised by positive laws to scupper the earlier domination of natural law perspectives and the Christian Church.

But natural law is still with us today, as are gods and churches, and numerous social norms and cultures. Law as culture is accepted but culture as law creates irritations. ${ }^{15}$ This appears to defy logic and indicates fuzziness in lawyers' brains. The simple triangular picture provided earlier indicates and confirms the global reality of a plurality of laws, especially if one changes this model to introduce broken lines:

13 See Hart HLA The Concept of Law $2^{\text {nd }}$ ed (Clarendon Press Oxford 1994) 91, Hart wrote of "primitive communities", which led him to argue that such people did not have "secondary rules" and thus had, in his perspective, no proper law.

14 This was also one of the key arguments in an earlier study by another reluctant pluralist who learnt, in this case, a lot about law and life in Africa. See Allott AN The Limits of Law (Butterworths London 1980).

15 See on this theme Cotterrell R "Law in culture" 2004 Ratio Juris 17(1) 1-14; Cotterrell R (ed) Law in Social Theory (Ashgate Aldershot 2006); Cotterrell R Living Law: Studies in Legal and Social Theory (Ashgate Aldershot 2008). 


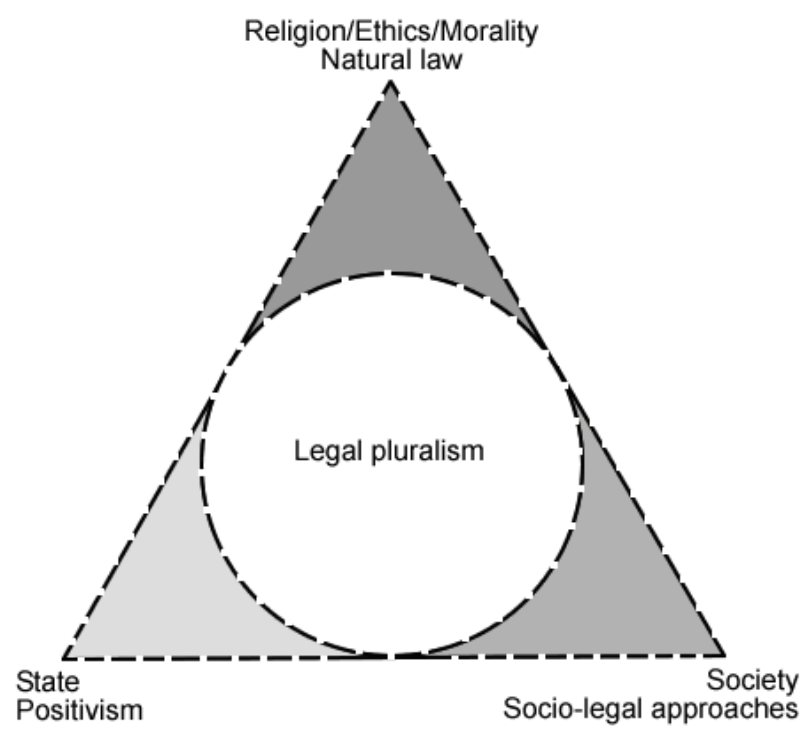

This triangle could be the globe; it could be Europe; it could be a state; it could also be our brain because as individuals we may all just be fuzzy triangular creatures who constantly struggle to make the right decisions. Law as an entity is not simply fuzzy, then; it is a complex multilayered plurality of pluralities, a deep "pop" structure. None of the three corners shown above is just a single uniform entity or theory; so another deeper level of "pop" structure exists, since all three corners are internally plural. The different numbers in the earlier graph further indicate the existing pluralities within the law. The clear message is therefore that law is internally plural at various levels and is super-diverse or super-fuzzy. It simply cannot avoid being its own other in the shape of "religion" or "ethics", social norms, state law and now, as we shall see, also international law and human rights. To claim that law is only state law is to play Vogel Strauss, as they say in German, burying one's head in the sand like an ostrich, because one cannot bear the fuzziness of legal reality.

For the benefit of newcomers to this super-fuzziness of law, or for those recalcitrant positivist souls that still need to be converted, I should explain briefly that the sequence of numbering in the diagram above was influenced by recognition that the cacophony of law is performed primarily in society, which I gave number 1. I then gave number 2 to the official law of the state, which has at least two types, ${ }^{16}$ statemade laws and state-accepted laws. I then added number 3 for the values attached

16 Also according to Chiba Asian Indigenous Law. 
to corners 1 and 2, relying again on Chiba (1986) who speaks of "legal postulates", another fuzzy concept, deliberately hiding that these values could actually be religious or secular. So here we have a first glimpse of the boundaries of secularism. ${ }^{17}$

The various numbers in the diagram above are indications of fuzziness, hybrid forms like Ehrlich's (1913) "living law", somewhere close to 12 and 13, and so on. It is evident that legal pluralism, fuzzy laws and overlapping social and legal identities are not only an issue in the UK, or in post-migration Europe, and arise not only in relation to Islam. Fuzziness, which Boaventura de Sousa Santos elegantly terms "interlegality", ${ }^{18}$ is a truly global phenomenon and is integral to what Emmanuel Melissaris now portrays as "ubiquitous law", ${ }^{19}$ without really saying anything new.

All this tells us quite descriptively that the global Garden of Eden is now an increasingly crowded place in which multiple competitions are being staged, inevitably leading to complex conflicts that we had better understand as well as possible before they arise, not only after the damage has been done. Significantly, the new fashion amongst human rights lawyers of engaging in post-conflict reconstruction often avoids debates about legal pluralism and thus remains unable to construct adequate solutions. This deficient methodology just appears to make an attractive new business out of repairing damage - or call it legal plumbing - after the disaster has occurred. It teaches nothing about prevention of disasters or more tolerance about choice-making by certain "others" because it studiously ignores pluralism. It offers no sustainable solutions for the future, since old paradigms are

17 There is clear-cut evidence that Chiba (1989:173) had earlier used the term "basic law" for "the system of values and ideals specifically relevant to both official and unofficial law in founding and orienting the latter". Chiba noted that this third level was"constituted of established legal ideas, religious precepts and teachings, social and cultural postulates related to fundamental social structure, or political ideologies often closely connected with economic policies. As this level forms the ideational foundation of the whole structure of law of a people, its variety of components must be capable of maintaining minimum integration in spite of some minor incongruities and conflicts among them." In a typically subtle comment, Chiba (1989:174) disclosed that he reacted to criticism of his efforts to navigate the boundaries of religion and secularism by simply changing his terminology to "legal postulate" since 1984, without substantial change in definition.

18 De Sousa Santos B Toward a New Common Sense: Law, Science and Politics in the Paradigmatic Transition (Routledge London 1995).

19 Melissaris E Ubiquitous law: Legal Theory and the Space for Legal Pluralism (Ashgate Farnham 2009). 
just recycled by almost religious recitation of neatly presented concepts such as legal transplants, uniformity and globalising uniformisation.

Since law remains everywhere culture specific and situation specific, however, there is simply no passe par tout. ${ }^{20}$ There might be convergence, but a little bit of plurality is still not total uniformity; the picture remains fuzzy. We should have learnt this from history, but continue to make the same theoretical mistakes repeatedly. Acceptance of legal pluralism and of "pop" in the form of tolerance of religious and social diversity remains also practically important, as the latest evidence of ethnic cleansing in Kyrgyzstan shows, where that dirty fuzzy word "ethnicity" surfaces again and difference is blamed for crazed conflict.

\section{Part III}

Lawyers, politicians and many others have found it rather convenient to criticise "religion" and "culture" for the polluting fuzziness of law. Lawyers' tendency to prejudge seems here more like a clever distraction, hiding the cluelessness of most lawyers about theories of legal pluralism, and covering up chronic myopia. Critical comments are pertinent for this lecture. Contrary to mythology in the SOAS boot camp of human rights, I am concerned with finding sustainable methods to secure human rights, but emphasise the challenges of interculturality, which few human rights lawyers - and many others - appear equipped, or even ideologically prepared, to accept.

This was demonstrated vividly by the Archbishop of Canterbury's Foundation Lecture on 7 February 2008 on "Civil and Religious Law in England: A Religious Perspective", which appeared to upset many people. ${ }^{21}$ I receive enough hate mail as it is, so I refused to speak to journalists after this lecture because I had said and written similar things to the Archbishop at least ten years before his talk. ${ }^{22}$ Today, though, I am prepared to face the music in public, for Marie-Claire and RELIGARE.

20 The internal plurality of international law is increasingly recognised, but appears to create a new language rather than linking into existing pluralism studies. See Wagner A and Vijay KB (eds) Diversity and Tolerance in Socio-Legal Contexts: Explorations in the Semiotics of Law (Ashgate Farnham 2009).

21 See http://bit.ly/em8ttV [date of use 29 Nov 2010].

22 See, for example, Pearl D and Menski W Muslim Family Law $3^{\text {rd }}$ ed (Sweet \& Maxwell London 1998), especially Chp 4 on conflicts of law and the notion of British Muslim law, angrezi shariat. 
What Dr Rowan Williams said on 7 February 2008 was thus highly relevant for us here. He spoke of the growing challenge in our society by the presence of communities, "which, while no less 'law-abiding' than the rest of the population, relate to something other than the British legal system alone". The Archbishop was talking in code here about legal pluralism and the fuzziness of law, and he mentioned specifically Muslims and Shari'a, while emphasising that this was a much wider issue. Without using that dirty word "pluralism", and from his perspective as a church leader, he highlighted the rights and position of religious groups within a secular state. Talking about law and religion, the Archbishop was flying a kite. We all know that this kite was shot down by a volley of heated criticisms that the Archbishop, of all people, had overstepped his limits by suggesting that there should be a place for Shari'a Law within the English legal system. Actually, he never said that in the lecture itself.

Recently, we saw a late counter-volley, another kite being flown above Britain. On 17 June 2010, a new report was posted by the No Sharia Campaign, a group operating under the label "One Law For All", created in December 2008, probably in reaction to the Archbishop's speech. The title of this report says it all: "Sharia Law in Britain: A threat to one law for all and equal rights".

One can interpret this string of words in various ways. Shari'a Law in Britain is clearly a threat to the credibility and plausibility of the One Law for All campaign. So is here just another self-interested NGO that cleverly claims to protect the rule of law, human rights and, significantly, equal rights? The blurb tells us explicitly that this campaign group opposes the existence of all kinds of religious courts. No fuzziness here: law is simply state law and we must have one law for all. Private dispute settlement is out, no multicultural ADR! Tony Blair asserted exactly the same position and then silently created Islamic banking law in the shadow of English law after $9 / 11$ to strengthen London's position as a global finance capital. So when it helps us, we co-opt Islam. 
The official credo remains, however, that the positivist boat cannot be rocked and the state must be in total charge of our lives. Frightening stuff; have a close look. ${ }^{23}$ This publication is thin on substance, full of rhetoric and displays militant intolerance towards anything religious, demonstrating that there are still many people who have neither the will nor the capacity, it appears, to engage deeply in the issues with which RELIGARE is concerned.

Now let us see how the Archbishop of Canterbury concluded his speech in February 2008. Here is a public intellectual at work, a plurality-conscious theorist in the shape of a head priest - certainly not a fuzzy mind - rather a mature man with a fuzzy beard, very much like Prof Veit Bader, to whom we come in a moment. Clearly, the Garden of Eden with its forbidden apples of law is not only accessible to social philosophers or law professors. This is what Dr Rowan Williams said at the end:

In conclusion, it seems that if we are to think intelligently about the relations between Islam and British law, we need a fair amount of "deconstruction" of crude oppositions and mythologies, whether of the nature of sharia or the nature of the enlightenment. But as I have hinted, I do not believe this can be done without some thinking also about the very nature of law. It is always easy to take refuge in some sort of positivism; and what I have called legal universalism, when divorced from a serious theoretical (and, I would argue, religious) underpinning, can turn into a positivism as sterile as any other variety. If the paradoxical idea, which I have sketched is true - that universal law and universal right are a way of recognising what is least fathomable and controllable in the human subject - theology still waits for us around the corner of these debates, however hard our culture may try to keep it out. And, as you can imagine, I am not going to complain about that.

This recommends the deconstruction of law and challenges positivism and legal universalism. It almost says that we should respect fuzziness. This tongue-in-cheek comment by a religious leader is a gust of wind to shake the kites of state-centric legal positivism. Of course, this gravely irritated the militant ideologists of uniformising secularism. It was designed to do just that, since the speech mainly criticised intolerance of religion and emphasised the important place of religion and ethics in today's world, which is dominated by a definite predilection for secularism and continued panic about religious diktats. The main message about the continuing relevance of religion pleads for recognition that natural law and values, whether

23 See http://bit.ly/BW2Tp [date of use 29 Nov 2010]. 
religious or secular, ${ }^{24}$ should continue to be accounted for. Somewhere in the middle of the speech, the Archbishop said very clearly and without any verbal fuzziness that "this means that we have to think a little harder about the role and rule of law in a plural society of overlapping identities". So it appears that this religious man with the fuzzy beard is a much better pluralist lawyer than many law professors.

\section{Part IV}

Let us consider the Archbishop's speech now in the specific context of RELIGARE, which aims to provide sustainable policy guidance about the manner in which to manage the never-ending diversities of law in today's multi-religious and multicultural Eurozone. This promises assistance in the manner in which to navigate the kites of legal pluralism that every single state in Europe has to fly now. It is certainly timely that Europeans should consider such questions, since we cannot just ban requests for minarets or criminalise all people who wish to wear a particular religious dress or a specific hairstyle, though that seems to be the trend at present in the Eurozone. But do we know enough about kite-flying? I am aware that some of you are waiting for my spiel on that; please wait just a little longer. First, to create some focus, let us consider this credo of RELIGARE: "RELIGARE starts from the idea of equality and how it is challenged by the increasing diversity of religions and other convictions that are transforming Europe into a new type of entity".

Assuming that this elegant phrase and specially the highlighted portion comes from Marie-Claire, my initial worries about its meaning were calmed, because I know that she is plurality conscious and has what SOAS law students now call "fish eyes", the ability to capture the whole globe in one's gaze. "Equality" is, however, rather too quickly perceived by many lawyers, policy-makers and common people as "sameness" or even "the same as me", especially argued by majoritarian people without plurality consciousness, those with the blinkered eyes, "fishy eyes" as one of my less clever students wrote in an essay earlier this year.

24 In combination with other "pop" elements of law, I hasten to add here. We forget all too easily in such debates that "society" and "culture" are also legally relevant elements. See the earlier references to Cotterrell (n 14 above). 
Lack of sensitivity and respect for the needs of others is becoming really dangerous for management processes of religious and cultural diversity in European states. We appear to be violating principles of equality in questionable efforts to force unequals to become equal, and really to become like us. Is this why we stipulate higher minimum marriage ages for certain immigrants or make them pay extra for the privilege of coming to Europe while relying on Diceyan dogma? We have simply been sliding into harsh and biased, or as Hanne Petersen would say, "graceless", approaches to assimilation, integration, accommodation, inclusion and criminalisation, if not expulsion, of "the other". States target and criminalise some kinds of otherness, but accept new other developments at the same time, with huge question marks over the criteria chosen. ${ }^{25}$ We constantly pre-judge; but what are our criteria? Where are the boundaries of reasonableness? The problems have become so grave now that more and more activist thinking has emerged, finally bringing together theorists, practising lawyers and human rights advocates in this RELIGARE project, which is so productive precisely since it creates new opportunities for questioning one another's fuzziness. Perhaps we have to be a little fuzzy to get involved in this project. That does not mean we have to give up our values, though. But we are asked, collectively and individually, for a great deal of tolerance; more about that in a moment.

The RELIGARE team, with some healthy reservations about where and how to draw various critical boundaries of acceptance, appears to broadly agree now that starting from a premise of seeking to protect equality as a core value, the new multicultural Europe simply cannot close its eyes to religious and cultural diversity. But within that broad acceptance of diversity and difference as a fact, there remains much fuzziness of methodology, which Workgroup 1 will have to tackle in the coming months to make any significant progress. Do we accept social diversity and multiple identities,

25 Poulter S Ethnicity, Law and Human Rights: The English Experience (Clarendon Press Oxford 1998), argued in the concluding discussion that English law through its courts was able "to mould the law to take account of an increasingly diverse population" (391), but gave convenient examples of attitude changes only within majoritarian society. Poulter then provided his not so liberal final words on policy, reiterating that "there will inevitably be certain key areas where minimum standards, derived from shared core values, must of necessity be maintained, if the cohesiveness and unity of English society as a whole is to be preserved intact" (391). More recently, similar issues of governance and navigation have been picked up by Osterlund K "Love, freedom and governance: Same-sex marriage in Canada" 2009 Social and Legal Studies 18(1) 93-109. 
but not legal pluralism? And if so, why? Everywhere, so much is clear: we are facing contested fuzzy boundaries.

Looking around, though, we realise that RELIGARE is not alone. All over Europe, there is growing recognition that religious and cultural dimensions cannot be neatly segregated from law. Sweden, of all places, funded its own ten-year project at Uppsala Universitet for 2008 to 2018, titled "The impact of religion: Challenges for society, law and democracy". ${ }^{26}$ There have been some protests about public money being spent on such a backward-looking programme, which encourages young scholars to explore boundary studies involving religious and cultural issues. One even tried to fail the first $\mathrm{PhD}$ student to come out of that project. This indicates that the One Law For All campaign is not just a British disease; it is a Euro-phenomenon, with many global implications.

Significantly, the Swedes, too, have realised that modernity did not completely eradicate religion. The so-called "secular state" remains in fact fuzzily connected to certain religious values, in this case Lutheran, as recently seen in the royal wedding, which created other storms in a tea cup. Of more relevance to us here than whether a future queen should be allowed to marry her fitness trainer is another issue of diversity. If more than $20 \%$ of your nation's population are what the Dutch call allochthones, fuzzy "others" in perpetuity, though this posh term desperately hides the dirty words "race" and "ethnicity", the supposedly shared values in a state-centric legal system are going to be under challenge. As noted for Britain by the Archbishop of Canterbury, it then becomes not so paradoxical that the dominant culture finds it difficult to assert itself and that certain allowances will have to be made. But what are the boundaries, and what allowances are we prepared to make?

\section{Part V}

Fortunately, I need not explain this here in detail. The familiar key issue is who sets the standards and who determines the guiding norms. Roger Ballard's work about skilled cultural navigation, in his brilliant introduction to Desh Pardesh, ${ }^{27}$ helps to identify the issue spot on: agency for navigation is actually a fuzzy set. It is neither

26 See http://bit.ly/igLQVE [date of use 29 Nov 2010].

27 Ballard R (ed) Desh Pardesh: The South Asian presence in Britain (Hurst London 2007 [1994]). 
fully determined by the state nor by the ethnic majority; there are always many diverse responses. Ballard even suggests that the majority may be disadvantaged, since certain members of minority communities may become more skilled navigators than the monolingual majority. So some polyglot BrAsians, as they are now called, ${ }^{28}$ may become top kite flyers and then take over everywhere if the autochthonous Europeans are not careful. One already sees this new glocalised cosmopolitanism in the city of London, while the informal corporate environment of hawala transactions raised enough worries to motivate terrorism-related investigations. ${ }^{29}$ From this perspective, RELIGARE looks more like a self-defence operation of the whitedominated Eurozone. We realise the danger of losing control of "our" Eurozone, as it becomes more and more pluralised. Whether this is reverse colonisation or simply glocalisation in borderland territory will be assessed quite differently throughout the Eurozone, but it is undeniable that such fears exist and are apparently growing.

\section{Part VI}

By now, then, several things have become crystal clear. Firstly, law is fuzzy and internally plural, with several levels of "pop" plurality within it. It is simply a matter of common sense and realism to accept that. Those who do not subscribe to such a vision can still leave RELIGARE, and their funds will then be allotted to others. Secondly, and equally clearly, "religion" is also an internally plural phenomenon with many "pop" elements. We need not discuss this here. Thirdly, secularism must then also be a fuzzy concept. Hence, any talk about the boundaries of secularism becomes irritating noise not only for people who do not like pluralist fuzziness, but also for those who wish to ban religion from the sphere of law.

What is also crystal clear by now, however, is that "law", "religion" and "secularism" as concepts and global phenomena are all intrinsically linked through the basic principle of interconnectedness, which looks to me rather like karma, the basic principle of action and reaction. We should not just think about the familiar Buddhist bank balance; let us go deeper to the roots of this concept. It implies that as individuals we are not really a law to ourselves, can simply live our own religion, or

28 Ali N, Kalra VS and Sayyid S (eds) A Postcolonial People: South Asians in Britain (Hurst London 2006).

29 Access details from the Centre for Applied South Asian Studies under http://bit.ly/ehg8yP [date of use 29 Nov 2010] operated by Dr Roger Ballard. 
cultivate some absolutely autonomous secular conviction, as Marie-Claire would call it. Individual idiosyncratic lives are inevitably, visibly and invisibly, linked to social groups, states, global humanity, really everything. These entities are all semiautonomous, Sally Falk Moore would say. ${ }^{30}$ So, life itself is fuzzy. We know that we play a number of roles as individuals, members of social groups, citizens, and global kite flyers. And in all of this we are inevitably wired up and interconnected, as Chiba (1986) taught us, through the stringy elastic glue of values and identity postulates, whether religious or secular. ${ }^{31}$ We are culture-specific semi-autonomous individuals with much fuzziness. The plurality-conscious handling of such interconnected entities lies at the centre of RELIGARE's brief; it forms a core concern of human coexistence in the twenty-first century. In this postmodern age we realise, maybe especially as we grow older, that the concept of the autonomous individual is a good idea and is a really brilliant theory, but living law constantly ensnares us in pluralist fuzziness. Again, do we now revise our judgments?

\section{Part VII}

How, then, do we define the boundaries of secularism? If law and religion remain connected, precisely because law is fuzzy, law is not just state law and is inevitably never value-neutral. Thus, the core question becomes: how do we deal today with anything "religious" and what do we do with the various claims of secularism to a privileged place within this fuzzy discourse? Again, as I shall demonstrate in a moment, we love to pre-judge what is religious and what is not and constantly fall into traps of our own making.

At this point again, I can be fairly brief because Prof Veit Bader has done us a huge favour by contributing his excellent essay on the twelve kinds of secularism, first presented for the Leuven meeting and then sent to me recently, clearly a signal that I must discuss it tonight. ${ }^{32}$ The paper is extremely relevant and constitutes hard labour in the exploration of the fuzzy boundaries of secularism, but the conclusions are

30 Moore SF Law as Process. An Anthropological Approach ( Routledge and Kegan Paul London 1978).

31 See $\mathrm{n} 10$ and 15 above.

32 I assume that implies permission to refer to it here. See Bader V "Constitutionalizing secularism, alternative secularisms, or liberal-democratic constitutionalism? A critical reading of some Turkish, ECtHR and Indian Supreme Court cases on 'secularism'" 2010 Utrecht Law Review 6(3) 9-35. This article forms part of the RELIGARE Additional Materials for 4 to 5 February 2010. 
questionable and actually rather intolerant. There is even a final recommendation to throw out the concept of "secularism" altogether because it is too fuzzy and there is too much confusion over what this concept means.

I do not think this is a constructive suggestion. Do we then also throw out the concept of "law" because it gives rise to problems in our understanding? Expunging a concept or term because nobody can make full sense of it strikes me as nihilistic abandonment of scholarly responsibility. I suggest we have to live with troublesome fuzzy secularism and its threatening implications, just as we have to live with fuzzy law and its many unpleasant consequences.

Bader's paper offers, however, notable insights into the lack of comprehension displayed by Indian judges of secularism in India. Now, I am not going to launch into a lecture on Indian secularism here. ${ }^{33}$ But let us note that the wonderful ideal of Indian secularism as "equidistance of the state from all religions" is neither trusted globally, nor fully accepted or understood by many modern Indians themselves, those with the colonised minds. This "pop" element is so confusing and muddled that several more books will need to be written on it.

Bader stumbles onto something really spicy here, smelling that the Indian state actually manages a somewhat soft system of interlinkedness of law and religion, different from French-style laicist separation or the US model of non-establishment. $\mathrm{He}$ senses that while the Indian legal system and its functionaries do not fully understand this fuzziness, people are deeply conscious of the notion of "unity in diversity". ${ }^{34}$ For me as a South Asia specialist, this is just another culture-specific term for "pop", but even Indian Supreme Court judges, mostly brainwashed by positivist Western training, remain deeply confused about such notions. While admitting a role for religion in Indian law today is officially seen as unconstitutional,

33 It appears that a detailed analysis would necessitate a whole new piece of research on the precise meanings in classical Sanskrit and today's Hindi of a concept that was well-established by ancient Indians as seen in Sanskrit references like "dharmanirapekshavāda", translatable as "the theory of the impartiality of dharma", and thus maybe "secularism". This term certainly has many shades of meaning, including the politically well-known "non-alignment". It is clearly another super-fuzzy concept that awaits deeper analysis.

34 Derrett JDM Religion, Law and the State in India ( Faber \& Faber London 1968) discusses such notions in detail. 
the world is being led to believe by an unholy alliance of secular scholars and human rights activists that the Indians run a fascist Hindu theocracy.

Clearly, something does not add up here, probably because we are prejudging again. Yes, there is communal violence in India, but blood flows in Blackburn, Berlin, Bratislava and not just in Bombay or Baroda. The Indians have somehow been teaching their now almost 1.2 billion citizens - many more than the whole Eurozone together - through modern constitutional interventions that remain inadequately studied, that the key concept of dharma, the duty to do the right thing at any time of your life, is not just a Hindu term, but is a globally valid concept that can be applied anywhere. We cringe, of course, and dismiss such deep thinking as fascist hindutva, Hindu nationalism. But who are we to pre-judge a culture and a religion without studying it properly? When we simply classify and dismiss anything Hindu or Muslim as religious, ${ }^{35}$ for us there is no fuzziness any more; for us, these entities are just polluted and deemed backward by association with religion. But they are also living realities, and they are fuzzy.

India's constitutional dharma as an unspoken and current interlinking reality, we need to realise, binds Indians of all creeds as citizens under the same, secular Constitution. These are fuzzily shared common values, it appears. Of course, the Indian Constitution does not explicitly mention dharma because the postEnlightenment world would just scoff. And by now, the Indians are so ashamed of their own culture that they, including their judges, are mentally blocked from clear thinking about the boundaries of secularism. Veit Bader's analysis spots all of this, smells the spicy masala of dharmic plurality - and then decides to throw it into the dustbin of history. What a pity! Are we just afraid of masala? Can we not go deeper in our analysis?

35 For details, see Menski W "Hindu law as a 'religious' system" in Huxley A (ed) Religion, law and Tradition: Comparative Studies in Religious Law (RoutledgeCurzon London 2002) 108-26; Menski W Hindu Law: Beyond Tradition and Modernity (Oxford University Press New Delhi 2003). 
Most common Indians instinctively know that dharma is not just religious or "Hindu". ${ }^{36}$ Rather, it is a civic concept in which the fuzzy boundaries of religion, law and secularism are less relevant than the question whether appropriate, situationspecific and just solutions can be found. Where situation-specific justice is the ultimate goal, the boundaries of equality and difference become contested, and equity has become the not-so-new tool to achieve appropriate balances between newly emerging competing equalities. ${ }^{37}$ Some Indian judges have actually been quite explicit about this, but an increasingly globalisation-focused audience has not taken this seriously. ${ }^{38}$ We in the West have not picked up those sounds, nor do we wish to pick them up, because the underlying message amounts to a rejection of the colonial legal order, also of simplistic transplant ideology. The advice has been that careful sifting of Euro-values is needed also in post-colonial India to create a culture-specific new legal order, which would necessarily be fuzzy and internally diverse. We may realise that this sounds not unlike the challenges faced by post-migration Europe.

We simply do not realise that the Indian state has since 1947 gradually prevailed on all citizens, Hindus, Muslims, and all others, to bring themselves within the so-called basic structure of the Indian Constitution, but without mentioning dharma. Nobody knows where the fuzzy boundaries of this basic structure exactly are, but definitional criteria relate to situation-specific justice and constant dynamic processes of finetuning. All we are told to see is that association with Hinduism pollutes dharma; so we still fear religious diktats by men in orange clothes and long beards. Yes, they may raise their voices, even in British courts, but RELIGARE wants to develop

36 Probably most Indian Muslims know this, too, and they are similarly aware of the internal diversity of Shari'a. I can only reiterate here my statement that "[a] good Muslim is therefore, of necessity, a pluralist" (Menski 2006: 281, as n 7), evidently more so in some parts of South Asia than in Pakistan or in the Middle East.

37 On an earlier phase of legal development, see Derrett JDM "Justice, equity and good conscience in India" in Derrett JDM (ed) Essays in Classical and Modern Hindu Law Vol 4 (Brill Leiden 1978) 8-27. An excellent sample of new equity is India's development of the post-Shah Bano maintenance regulations for all divorced wives, on which see Menski W "The Uniform Civil Code debate in Indian law: New developments and changing agenda" 2008 German Law Journal 9(3) 211-250.

38 Chief Justice Bhagwati in MC Mehta v Union of India [1987] 1 Supreme Court Cases 395420 , openly proclaimed: "We have to evolve new principles and lay down new norms which would adequately deal with the new problems which arise in a highly industrialised economy. We cannot allow our judicial thinking to be constricted by reference to the law as it prevails in England or ... in any other foreign country. We no longer need the crutches of a foreign legal order. We are certainly prepared to receive light from whatever source it comes but we have to build our own jurisprudence." 
methods to handle exactly such irritations. We also need to know more about the reasons that certain borderline issues are raised, and the reasons that there are some repeat players that appear to manipulate the agenda and our discussions.

Partly infected by contagious fears of such religious fuss, Veit Bader suggests expunging secularism and proposes focus on LDC. Clearly, we academics love new terms. LDC is not a new category of gender fuzziness, but stands for a potentially radical secular entity: Liberal Democratic Constitutionalism. The trouble with this concept and its anticipated use is that it appears to ban "religion" from the sphere of law and privileges statist positivism as the ultimate arbiter of justice. It separates "law" and "religion", and looks like a model; therefore, that is out of date and not suitable for countries like India, indeed for the world.

So, for example, Bader observes correctly that LDC appears to mean implementation of a Uniform Civil Code in India. ${ }^{39}$ But I am sorry to tell you that he talked to the wrong people. State-centric management in Indian law remains a tempting thought for many Indians, but resurrects grave doubts whether we can trust the state. When the Indians had a nationalist BJP government a few years ago, they actually realised that state-centrism would mean Hinduisation. The BJP itself realised that this would be unworkable and would actually be unconstitutional. The unspoken basic structure foundation of dharma thus saved India from selfdestruction, precisely because it remains fuzzy about the boundaries of religion and secularism. In fact, dharma encompasses both. Fuzziness, this suggests, is more practically useful than we realise and care to admit.

\section{Part VIII}

So the question for Europe becomes whether such an intriguingly fuzzy concept can be recycled and repackaged for the Eurozone. Suggesting eurodharma as a wonder drug for the aches and pains of multicultural Europe will irritate many of you, and I am certainly not a Hindu missionary. But this is the envisaged hopeful sub-title for my talk. It suggests that with less noisy panic about "religion" and reduced fears

39 A 44 of the Constitution of India, 1950, provides that "[t]he State shall endeavour to secure for the citizens a uniform civil code throughout the territory of India". What exactly this may have meant around 1950 and what it may mean today remains in need of much debate. It certainly did not involve the end of personal status laws (see Menski 2008 German Law Journal). 
about religious diktat, we might cultivate clear-headed readiness to listen to the harmonising sounds coming out of India about the way in which to manage a whole continent on the basis of an unspoken fuzzy Hindu notion, while accommodating more than 150 million Muslims, many more than we have in Europe today.

Article 51A of the Indian Constitution does refer to the duty of all citizens to respect the country's composite culture. ${ }^{40}$ Here is another word for fuzzy, a simple and less dirty word, "composite". It asks for tolerance and indicates different components. So could we compose a new eurodharma and perhaps call it a eurohymn for our composite Europe, or for the various composite nations of Europe? Or do we wish to persist in claiming that law and culture are not related, that "law" is just a boxed, separate entity? The new composition will of course need to include some "dirty" elements, such as difference or diversity, but also nicer notions such as democracy and decency. Maybe we can even compose a full eurosymphony, given that Esin Örücü writes so elegantly about law as an orchestra. ${ }^{41}$

While fear of religious diktat remains clearly a prominent modernist phobia, this must in our postmodern age be put in perspective. My work on Hindu law demonstrates clearly that the Hindus would not even know where to look for a religious diktatmaker, because there is no one god that could act like Napoleon. ${ }^{42}$ Manu is just an old skeleton in the cupboard of Hindu law, certainly not a law-maker. Orientalism appears to have constructed a faulty vision, and now Indian colonised minds repeat the nonsense, sold in paperback editions of Manu's Code. ${ }^{43}$ This tells us a great deal about the powers of publishers to manipulate worldwide and seriously outdated perceptions of Indian law, which hold back a plurality-conscious global analysis.

40 Part of the Fundamental Duties under A 51-A in the Indian Constitution of 1950 as amended in 1976, A 51-A(f) lays down that it shall be the duty of every citizen of India "to value and preserve the rich heritage of our composite culture".

41 Pertinent questions over politics and who would conduct such an orchestra were raised immediately after this lecture and it is evident that there is much to debate. On various contributions of comparative law, see Örücü E The Enigma of Comparative Law: Variations on a Theme for the Twenty-First Century (Martinus Nijhoff Leiden 2004).

42 See Menski "Hindu law as a 'religious' system".

43 See Doniger W and Smith BK The Laws of Manu (Penguin New Delhi 1991). More recently, maintaining such misleading images, see Olivelle P Manu's Code of Law. A Critical Edition and Translation of the Manavadharmasastra (Oxford University Press New Delhi 2006). 
The much bigger risk today remains that excessive reliance on state law can everywhere quickly be abused, and so can social norms of course, and even the sheep's clothes of human rights norms are perceived as "monsters" by many people around the globe. ${ }^{44}$ So we cannot trust anyone; we cannot even trust ourselves. Is there a way out of this nihilist negativity? Let us dig just a little deeper in our final analysis.

\section{Part IX}

I wonder if there is some scope for my recent kite model to become relevant for the project of RELIGARE and whether lawyers should construct not a eurosymphony, but perhaps a eurokite. This new kite structure is currently being fine-tuned and one should notice the re-numbering to reflect the historical shift over time from corner 1 at the top (natural law) towards corner 2 on the right hand side (social norms) to corner 3 on the left (the various state laws) and now corner 4 at the bottom (various concepts and forms of international law and human rights).

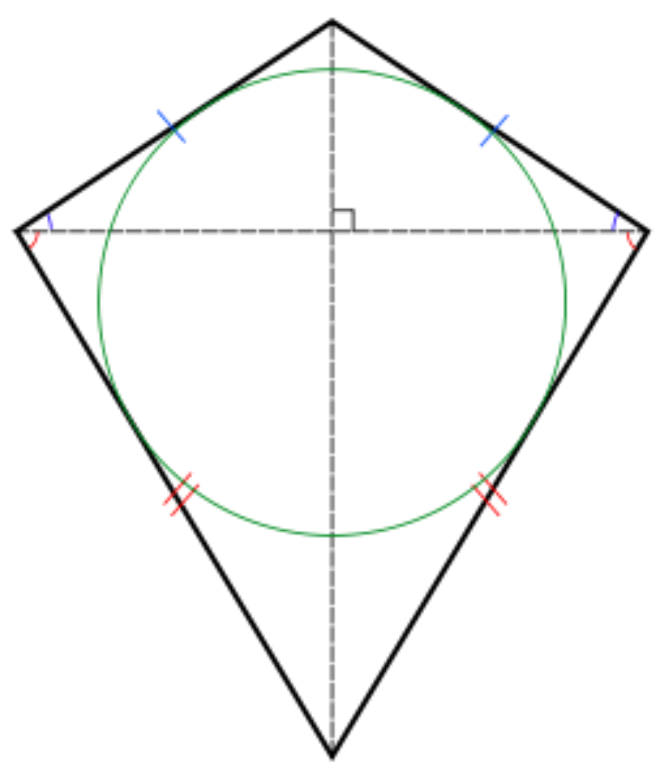

All I did, then, is add a fourth corner to the triangle as shown earlier, now to include international law and human rights as another "pop" element in the fuzzy superstructure of law. I found in the past two years that this simple image makes

44 See Menski Comparative Law. 
instant sense in many parts of the world. ${ }^{45}$ Imagine a sky full of kites - nice breeze, graceful movements - and then there are all those crashes and turbulences that cause havoc. Kite-flying is a high-risk activity: but so are law and life.

Some interesting thoughts have emerged recently amongst lawyers about certain methods of handling the increasing diversities in our midst and RELIGARE seems to create productive synergies. One element is the focused use of equity. ${ }^{46}$ All over Europe, we find examples of that old technique of making strategic exceptions in certain situations to avoid hardship and injustice. ${ }^{47}$ Further, many states are familiar with making special rules for certain groups of people, without sliding into the Ottoman millet system of personal status laws. We have amazingly clear-cut examples of such situation-specific management of diversity from all over the Eurozone. Thirdly, and this was also a hidden message in the Archbishop's lecture, tolerance of diversity must have limits, indeed. So there is something to be said for the concept of "intolerance of intolerance", which Arvind Sharma developed with reference to India and the need for Hindus to avoid being deprived of recourse to their own values and concepts. ${ }^{48}$ It is noteworthy that in later publications by the same prominent author, this concept appears to have vanished, probably since it appeared to many to justify communal violence. But where are the limits of tolerance? All over the globe, we struggle with that question.

My final suggestion is, therefore, that we rid ourselves of the modernist blindness and colonial tummy aches that we are experiencing especially in Britain and some other countries in Europe now when erstwhile colonial subjects use their ethnic

45 See Menski W "Flying kites in a globalizing sky and dodgy weather forecasts: Accommodating ethnic minority laws in the UK'" 2009 Journal of Multilingual Multicultural Studies and Practices 2 26-45 (in Japanese with an English abstract).

46 See excellently a recent draft working paper from Spain: Bengoetxea J 2010 "Multiculturalism and legal pluralism: European perspectives", which suggests lack of co-ordination amongst various kinds of lawyers "who must cope with the fragmentation and plural condition of law among other rules systems, seeking justice in concrete instances, seeking equitable, fair solutions" (1-2).

47 For England, see Chief Adjudication Officer v Kirpal Kaur Bath [2000] 1 FLR 8 CA and the way in which the court of appeal was forced, in order to avoid injustice, to acknowledge the legal validity and thus legal effects of an unregistered Sikh religious marriage in London some 40 years earlier. See also the unreported mahr case of Ali v Ali in 2000, first discussed in Menski W "Immigration and multiculturalism in Britain: New issues in research and policy" 2002 KIAPS: Bulletin of Asia-Pacific Studies XII 43-66.

48 Sharma A Hinduism for our Times (Oxford University Press Delhi 1996). 
implants of "unofficial laws" to claim more formal legal recognition, ${ }^{49}$ establish unofficial Shari'a councils and tactically demand all kinds of things, whether fullfledged personal laws or open air cremations to avoid alleged distress to Hindu souls in the UK, as happened in the recent Ghai case.

Several speakers in the RELIGARE seminars indicate that we should become a little more liberal in our democratic constitutionalism and should practise with more circumspection what Tariq Modood terms "moderate secularism". It appears that my arguments and Modood's suggestions are broadly in line with Bader's ideas about LCD, especially when he finally talks about soft liberal democratic constitutionalism, realising that, as in India, while the state remains the final arbiter, it should not seek to control everything, quite contrary to what the One Law for all Campaign suggests.

We are on to something really productive here, then, contemplating softer forms of drawing boundaries rather than supporting aggressive claims and domineering or punishing positioning by state legal systems. We should at least consider whether the concept of dharma, which like Shari'a is both religious and secular at the same time, and is thus super-fuzzy, is not something useful for the whole of Europe, if only because speaking of dharma takes away the focus from the current obsession with Shari'a. The concept of Euroshari'a would of course please some people, but like eurodharma, it would probably be ideologically unacceptable for the Eurozone, and thus would be shot down as a kite and made to crash unless we gave it different names. But the principle seems valuable and practically useful. Doing what is right, for yourself, for your group, for your country, and also for human rights, trying to do what is appropriate in any specific scenario of life, sounds like a globally desirable element of human existence and thus a solid building-block for the basic structures of individual behaviour and good governance. The trouble is that this choir of competing voices may all too easily become an irritating noise. The various efforts to compose a pleasant symphony will simply run into trouble all the time.

If we can overcome our phobias about recycling tainted terminologies and calm our panics about religion, however, filling established terms with new meanings and thus

49 On this concept, see Menski Comparative Law 58-65. 
opening and expanding their boundaries rather than simply closing things off and pre-judging, this may be a useful way forward. Hence, let us fly more pluralist kites that take account of all four "pop" corners, engage in respectful conversations with all expressed needs, and then try to find the right balance to sail majestically at the right level of the global skies of law. It may sound too idealistic, and those who shout loudest will certainly abuse it, but that problem is not very different from what we have today. Everywhere on the globe, that fuzzy entity called "law" continues to experience difficulties in finding the right balance between competing expectations. If the kite model above teaches us anything, it is that all four corners of the kite are always present and that none of the four plural voices in this concert could and should ever be fully silenced. There is no need for flirting with God, a concept that Pascale Fournier has recently thrown into the debate. ${ }^{50}$ All we need is some collective secular ijtihad and respect for the voices of others. The ultimate limits lie in assiduously preserving intolerance of intolerance. That, I suggest finally, is another super-fuzzy challenge for all of us. One thing is already certain: an increasing number of Europeans would see simply blanking out religion and culture from law today as a manifestation of intolerance.

50 See Fournier P "Flirting with God in Western secular courts: Mahr in the West" 2010 International Journal of Law, Policy and the Family 1-28. 